\title{
KEEFEKTIFAN MEDIA PEMBELAJARAN BERBASIS MOODLE TERHADAP KEMAMPUAN PEMECAHAN MASALAH MATEMATIS MAHASISWA
}

\section{THE EFFECTIVENESS OF MOODLE-BASED LEARNING MEDIA ON STUDENTS 'PROBLEM SOLVING ABILITY}

\author{
Dian Mayasari ${ }^{1}$, Sadrcak Luden Pagiling ${ }^{2}$ \\ ${ }^{1}$ Universitas Musamus, mayasari_fkip@unmus.ac.id \\ ${ }^{2}$ Universitas Musamus, pagiling_fkip@unmus.ac.id
}

\begin{abstract}
Abstrak
Penelitian ini bertujuan untuk mendeskripsikan keefektifan dari penggunaan media pembelajaran berbasis moodle terhadap kemampuan pemecahan masalah matematis mahasiswa. Sample dalam penelitian ini ialah mahasiswa yang mengontrak mata kuliah Kalkulus 1 sebanyak 28 mahasiswa di Universitas Musamus. Penelitian ini termasuk penelitian praeksperimental menggunakan teknik analisis data One Group PretestPosttest Design. Instrumen yang digunakan dalam penelitian ini adalah angket respon mahasiswa terhadap penggunaan media pembelajaran berbasis moodle dan tes kemampuan pemecahan masalah mahasiswa. Hasil penelitian menunjukkan bahwa keefektifan penggunaan media pembelajaran berbasis Moodle dari nilai rata-rata angket respon peserta didik mencapai dengan kategori sangat baik. Perhitungan $\mathrm{N}$-gain adalah dengan kategori sedang. Uji Paired Sample T-test memperoleh hasil tingkat signifikansi (efektif). Hal ini menunjukkan bahwa antara pre-test sebelum menggunakan media pembelajaran berbasis Moodle dan post-test setelah menggunakan media pembelajaran berbasis moodle mengalami perbedaan yang signifikan Berdasarkan hasil beberapa uji disimpulkan bahwa media pembelajaran berbasis moodle dapat meningkatkan kemampuan pemecahan masalah.
\end{abstract}

Kata kunci: Edmodo, Keefektifan, Kemampuan Pemecahan Masalah

\begin{abstract}
This study aims to describe the effectiveness of the use of web-assisted interactive learning media in developing creative thinking skills. The sample of this paper is who contract Kalkulus 1. The number of students was 25 people. This research includes pre-experimental research using the One Group Pretest-Posttest Design. Learning using moodle media is carried out in six face-to-face and one post-test. The instrument used in this study was a student response questionnaire to the use of moodle learning media and tests of problem solving ability. The results showed that the effectivene ss of the use moodlelearning media from the average value of the students' questionnaire. The $N$-gain calculation in the medium category. The Paired Sample T-test resulted in a significance level of $0.00<0.05$ (effective). This shows that between the pre-test before using moodle learning media and the post-test after using moodlelearning media experiences a significant difference. Based on the results of several tests it is concluded that moodle media is effective in developing problem solving ability
\end{abstract}


Keywords: Edmodo, Efectiveness, Problem Solving Ability

\section{PENDAHULUAN}

Kalkulus 1 merupakan salah satu mata kuliah yang diberikan untuk mahasiswa program studi pendidikan matematika fakultas keguruan dan Ilmu Pendidikan Universitas Musamus. Materi yang akan dipelajari pada mata kuliah kalkulus ini ialah sistem bilangan real, fungsi, turunan, dan integral. Materi yang diberikan pada penelitian ini ialah turunan. Perkuliahan yang dilakukan selama ini secara teori,sehingga mahasiswa menajadi bosan untuk mengikutinya dikarenakan dosen menjadi satu-satunya sumber belajar. Mahasiswa dapat menyelesaikan masalah yang sama dengan yang diberikan oleh dosen di dalam kelas. Hal ini mengakibatkan jika mereka dihadapkan dalam permasalahan yang baru, cenderung tidak dapat menyelesaikan masalah tersebut (Dwi Susanti, 2018). Mata kuliah ini juga belum menggunakan media berbasis online sehingga mahasiswa tidak dapat meningkatkan kemampuannya di bidang pemecahan masalah (Dian. Mayasari, Natsir and Munfarikhatin, 2019; Kartika:Hendra, 2013).

Online merupakan salah satu solusi untuk membuat pembelajaran lebih menarik. Platform pembelajaran saat ini sudah banyak digunakan diantaranya google classroom, edmodo, google suite, moodle (Hatip and Listiana, 2019). Moodle merupakan salah satu media sosial yang sering digambarkan sebagai facebook (Soni et al., 2018; Dwi Susanti, 2018). Moodle merupakan perangkat pembelajaran sederhana yang digunakan untuk mempelajari materi yang biasanya diperasikan menggunakan smartphone. Aplikasi ini akan memudahkan siswa dan pendidik untuk berinteraksi secara online dimanapun dan kapanpun. Melalui media ini, mahasiswa dapat megingat pelajaran dan penguasaan materi pembelajaran yang baik dapat meningkatkan hasil belajar mahasiwa pada mata kuliah yang diajarkan (Sudianto, Dwijanto and Dewi, 2019).

Pembelajaran melalui media online diharapkan dapat meningkatkan kemampuan pemecahan masalah matematis, karena mahasiswa dapat mengembangkan kemampuannya dalam menyelesaikan masalah. Hamdan pada penelitian bahwa moodle dalam penggunaannya berpengaruh pada motivasi, kualitas pembelajaran, dan prestasi belajar (Smaragdina et al., 2020). Hatip dalam penelitiannya menyimpulkan bahwa terdapat hubungan yang baik antara minat dan hasil belajar dengan menggunakan pembelajaran berbasis edmodo (Hatip and Listiana, 2019). Chourishi melalui penelitiannya menyimpulkan bahwa moodle efekti digunakan dalam pembelajaran (Chourishi, 2015). Dalam penerapannya, moodle sangat diminati oleh mahasiswa tetapi jaringan merupakan kendala untuk mengaksesnya (Rizal and Walidain, 2019). Dalam penelitian ini akan dilihat keefektifan penggunaan melihat kemampuan pemecahan masalah mahasiswa denan menggunakan moodle dalam pembelajaran.

Salah satu kemampuan yang harus dimiliki oleh seorang mahasiswa ialah pemecahan masalah. Pemecahan masalah dapat memberikan kesempatan pada mahasiswa untuk menyelesaikan masalah dengan berbagai macam solusi (Rizal and Walidain, 2019; Winardi, 2015). Bagi dosen, dengan menerapkan pemecahan masalah dalam proses pembelajaran dapat meningkatkan kreativitas mereka dalam menyusun soal sesuai dengan kebutuhan.

Dalam menerapkan pemecahan masalah, terdapat beberapa indikator (Robson and Polya, 1946) yaitu: 1) memahami masalah, tahap pertama ini siswa dibimbing untuk memahami permasalahan yang dihadapinya dengan jelas, memperoleh gambaran secara lengkap dari apa yang diketahui dan apa 
yang ditanyakan serta bertanya di mana ada hal-hal yang kurang jelas dalam masalah tersebut. Tahap ini juga dapat dikatakan sebagai pondasi untuk melangkah pada tahap selanjutnya. Dalam proses pembelajaran matematika, siswa dikatakan dapat memahami masalah kalau ia mampu menuliskan semua hal atau data-data yang diketahui dan ditanyakan dari masalah tersebut (Siswono, 2018). 2) menyusun rencana/melaksanakan penyelesaian, Dalam tahap ini siswa dibimbing agar dapat mengidentifikasikan dan mampu untuk mengubah masalah menjadi lebih jelas, serta menyiapkan berbagai strategi atau metode untuk digunakan pada tahap selanjutnya. Pengalaman dalam menyelesaikan masalah, membuat siswa lebih kreatif dalam menyusun /merencanakan penyelesaian/solusi pemecahan dari suatu masalah.

Siswa dikatakan dapat merencakan penyelesaian jika mampu membuat sistematika langkah-langkah penyelesaiannya. 3)melaksanakan rencana/perhitungan, Jika rencana penyelesaian telah disusun, selanjutnya dilakukan penyelesaian masalah sesuai dengan rencana yang dianggap paling tepat. Dalam menyelesaikan masalah siswa diberikan kesempatan untuk menggunakan alternatif lain dalam memecahkan masalah tersebut atau cara menyelesaikan masalah boleh lebih dari satu kemungkinan jawaban. 4) Memeriksa kembali, Langkah terakhir adalah melakukan pengecekan atau memeriksa kembali atas apa yang telah dilakukan pada tahap sebelumnya. Siswa dibimbing untuk memeriksa apakah proses dan hasil tersebut sudah dikerjakan dengan baik dan benar. Dengan cara seperti ini, maka kesalahan-kesalahan yang mungkin ada pada tiga tahap sebelumnya akan terkoreksi kembali sehingga siswa mampu menyelesaikan masalah dengan tepat.

Moodle merupakan salah satu media pembelajaran berbasis online, dimana didamnya terdapat materi, penugasan, kusi, pemberian nilai dan dapat dibagi menjadi beberapa kelas sesuai dengan kebutuhan dosen (Sabran and Sabara, 2019). Keuntungan menggunakan moodleyaitu 1) Moodle menjamin kemudahan dan keamanan pengguna karena peserta juga dapat mengakses moodlemelalui aplikasi di handphone, 2). pendidik dapat mengumpulkan bahan dalam fitur library, 3) Moodlemenyediakan akses yang cepat dan mudah. 4) orang tua dapat mengetahui proses pembelajaran dan dapat berkomunikasi dengan pendidik, 5) pendidik dapat berbagi file, ide dan materi belajar dan pengetahuan karena memperoleh materi melalui Moodle (Dwi Susanti, 2018)

Dalam kehidupan sehari-hari, sering kita dihadapkan dengan adanya kesenjangan antara kenyataan dan harapan. Kejadian seperti ini diartikan bahwa kita menemui suatu masalah. Dalam usaha untuk mendorong siswa kemampuan berpikir siswa, digunakan konsep masalah dalam suatu situasi dan tugas. Guru meminta siswa menghubungkan informasi yang diketahui dan informasi tugas yang harus dikerjakan sehingga tugas tersebut menjadi hal yang baru bagi siswa (Mayasari, 2019). Masalah bagi seseorang juga ditentukan oleh adanya keinginan atau kemauan orang tersebut untuk dapat menyelesaikannya, meskipun ia mampu atau tidak mampu dalam menyelesaikan masalah tersebut. Suatu persoalan merupakan masalah bagi seseorang, Bila siswa belum mempunyai prosedural dalam menyelesaikannya. Siswa harus mampu mempunyai menyelesaikannya. Bila ada niat menyelesaikannya.

Masalah dapat diartikan sebagai suatu situasi atau pertanyaan yang dihadapi seseorang atau kelompok ketika mereka tidak mempunyai aturan atau prosedur tertentu untuk menyelesaikannya. Dengan demikian ciri suatu masalah (Syaiful et al., 2017) adalah: 1) individu menyadari/ mengenali suatu situasi 
(pertanyaan-pertanyaan) yang dihadapi. Dengan kata lain individu tersebut mempunyai pengetahuan prasyarat. 2) individu menyadari bahwa situasi tersebut memerlukan tindakan (aksi), dapat dikatakan masalah tersebut menantang untuk diselesaikan, 3) langkah pemecahan masalah tidak harus jelas penyelesaiannya.

\section{KAJIAN TEORI}

Moodle merupakan salah satu media pembelajaran berbasis online, dimana didamnya terdapat materi, penugasan, kusi, pemberian nilai dan dapat dibagi menjadi beberapa kelas sesuai dengan kebutuhan dosen. Keuntungan menggunakan moodleyaitu 1) Moodle menjamin kemudahan dan keamanan pengguna karena peserta juga dapat mengakses moodlemelalui aplikasi di handphone, 2). pendidik dapat mengumpulkan bahan dalam fitur library, 3) Moodlemenyediakan akses yang cepat dan mudah. 4) orang tua dapat mengetahui proses pembelajaran dan dapat berkomunikasi dengan pendidik, 5) pendidik dapat berbagi file, ide dan materi belajar dan pengetahuan karena memperoleh materi melalui moodle (Pratama and Ismiyati, 2019)

Dalam kehidupan sehari-hari, sering kita dihadapkan dengan adanya kesenjangan antara kenyataan dan harapan. Kejadian seperti ini diartikan bahwa kita menemui suatu masalah. Dalam usaha untuk mendorong siswa kemampuan berpikir siswa, digunakan konsep masalah dalam suatu situasi dan tugas. Pehkone (Siswono, 2018) guru meminta siswa menghubungkan informasi yang diketahui dan informasi tugas yang harus dikerjakan sehingga tugas tersebut menjadi hal yang baru bagi siswa.

Masalah bagi seseorang juga ditentukan oleh adanya keinginan atau kemauan orang tersebut untuk dapat menyelesaikannya, meskipun ia mampu atau tidak mampu dalam menyelesaikan masalah tersebut. Suatu persoalan merupakan masalah bagi seseorang,

1. Bila siswa belum mempunyai prosedural dalam menyelesaikannya.

2. Siswa harus mampu mempunyai menyelesaikannya.

3. Bila ada niat menyelesaikannya.

Masalah dapat diartikan sebagai suatu situasi atau pertanyaan yang dihadapi seseorang atau kelompok ketika mereka tidak mempunyai aturan atau prosedur tertentu untuk menyelesaikannya (Winardi, 2015). Dengan demikian ciri suatu masalah (Siswono, 2018) adalah:1) individu menyadari/ mengenali suatu situasi (pertanyaan-pertanyaan) yang dihadapi. Dengan kata lain individu tersebut mempunyai pengetahuan prasyarat. 2) individu menyadari bahwa situasi tersebut memerlukan tindakan (aksi), dapat dikatakan masalah tersebut menantang untuk diselesaikan, 3) langkah pemecahan masalah tidak harus jelas penyelesaiannya.

Kemampuan untuk memecahkan masalah pada dasarnya merupakan tujuan utama dalam proses pendidikan. Bila siswa memecahkan masalah yang mewakili dunia nyata, maka mereka akan terlibat langsug dalam perilaku berpikir. Dengan pencapaian suatu masalah secara nyata, siswa juga mampu mencapai suatu kemampuan baru yaitu mereka dapat menggeneralisasikan pada masalah lain dengan ciri-ciri formal yang sama.

\section{METODE}

Penelitian ini dilakukan di Universitas Musamus. Objek penelitian adalah mahasiswa semester genap tahun akademik 2019/2020 yang menempuh mata kuliah Kalkulus 1 pada Program Studi Pendidikan Matematika Fakultas Keguruan 
dan Ilmu Pendidikan. Jenis penelitian ini ialah penelitian kualitatif praeksperimental dengan one group pretest-postest design. Desain penelitian ini dilihat pada tabel 1

Tabel 1. Desain Penelitian

\section{Pretest}

$\mathrm{O}_{1}$

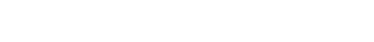

Pembelajaran yang dilakukan berbasis moodle dan diakhiri dengan pemberian tes (posttest). Populasi dalam penelitian ini adalah semua mahasiswa yang mengintrak mata kuliah Kakulus 1. Jumlah mahasiswa dalam penelitian ini ialah 25 orang. Teknik pengambilan sampil dengan purposive sampling yaitu dengan menentukan sampel dari berbagai pertimbangan tertentu. Pengambilan sampel juga sesuai dengan pertimbangan tertentu.

Teknik pengumpulan data yang digunakan pada penelitian ini berupa tes dan non tes. Teknik tes ini digunakan untuk mengukur kemampuan pemecahan masalah mahasiswa terhadap media pembelajaran berbasis moodle. Instrumen kemampuan pemecahan masalah berupa soal essay. Instrumen respon berupa agket tertutup dengan skala Likert.

Variabel dalam penelitian ini adalah pembelajaran mata kuliah Kalkulus dengan media berbasis Moodle sebagai variabel independen dan pemecahan masalah matematika sebagai variabel dependen. Analisis data yang digunakan antara lain analisis deskriptif dan analisis inferensial meliputi $\mathrm{N}$-gain, uji normalitas, uji homogenitas dan uji T-test (Paired Samples T-test). Analisis deskriptif untuk mendeskripsikan hasil dari proses pembelajaran berdasarkan data yang diperoleh. Skor angket akan berbantuan web dengan menggunakan statistik deskriptif. Rumus yang akan digunakan sebagai berikut:

$$
\text { Nilai }=\frac{\text { jumlahnilai yang diperoleh }}{\text { nilai maksimal }} \times 100 \%
$$

Dengan presentase skor yang diperoleh akan dikonversikan menjadi nilai kualitatif dengan empat kriteria diantaranya. Terdapat pada tabel 2

Tabel 2. Kriterian Interval

Interval

Kriteria

\begin{tabular}{cc}
\hline $100 \%<\mathrm{x} \leq 81,25 \%$ & Sangat Baik \\
\hline $81,25 \%<\mathrm{x} \leq 62,5 \%$ & Baik \\
\hline $62,5 \%<\mathrm{x} \leq 43,75 \%$ & Kurang Baik \\
\hline $43,7 \%<\mathrm{x} \leq 25 \%$ & Tidak Baik \\
\hline
\end{tabular}

Selanjutnya dilakukan analisis inferensial untuk beberapa uji. Tahap pertama ialah dengan melakukan pretest. Dengan tujuan untuk melihat kemampuan awal mahasiswa sebelum diterapkan media pembelajaran dengan edmodo. 
Untuk mengetahui tingkat keefektifan media pembelajaran berbantuan Moodle dapat dilihat dari hasil pretest dan posttest yang kemudian akan dianalisis meggunakan $\mathrm{N}$-gain dan uji T-test media pembelajaran berbasis edmodo. hipotesis yang disusun dalam penelitian ini ialah sebagai berikut:

$\mathrm{H}_{\mathrm{a}}$ : tidak terdapat perbedaan signifikan sebelum dan setelah menerapkan media pembelajaran berbasis moodle

$\mathrm{H} 1$ : ada perbedaan signifikan sebelum dan setelah menerapkan medi pembelajaran berbasis moodle

Tahapan selanjutnya ialah melakukan uji $\mathrm{N}$-gain untuk mengetahui peninkatan kemampuan pemecahan masalah matematis mahasiswa sebelum dan sesudah menggunakan media pembelajaran berbasis edmodo. kriteria keefektifan media pembelajaran berbasis moodle diadopsi oleh Meltzer (2002) seperti pada tabel 3 di bawah ini

Tabel 3. Kriterian N-gain (Rosdiana, 2015)

\begin{tabular}{cl}
\hline $\boldsymbol{N}$-gain & Kriteria \\
\hline $0,7 \leq \mathrm{N}$-gain $\leq 1$ & Tinggi \\
\hline $0,3 \leq \mathrm{N}$-gain $\leq 0,7$ & Sedang \\
\hline $\mathrm{N}$-gain $<0,3$ & Rendah \\
\hline
\end{tabular}

Tahap selanjutnya, melakukan uji normalitas dan homogenitas. Hasil yang diperoleh digunakan sebagai prasyarat Paired Sample T-test melalui uji Kolmogorov-Smirnov. Sama dengan hasil Lavene Test digunakan sebagai uji prasyarat Paired Sample T-test. Uji tersebut dilakukan dengan tujuan untuk mengetahui ada tidaknya perubahan nilai rata-rata yang dignifikan sebelum dan setelah menggunakan media pembelajaran berbasis moodle. ketiga tahapan tersebut diujikan menggunakan SPSS 20

\section{HASIL DAN PEMBAHASAN}

Dalam penelitian ini dilakukan, data yang dianalisis menggunakan deskripsi dan analisis inferensial. Analisis deskripsi menggunakan angket respon siswa terhadap penggunaan meida pembelajaran berbasis moodle. Sedangkan analisis inferensial menggunakan kemampuan pemecahan masalah.

\section{Respon Mahasiswa}

Angket yang digunakan terdiri dari 15 butir pertanyaan. Respon mahasiswa tersebut didistribusikan kepada seluruh sampel penelitian seteah diberikan tratment pembelajaran. . Hasil angket diperlihatkan pada Tabel 4 di bawah ini

Tabel 4. Respon mahasiswa terhadap media pembelajarn berbasis moodle
Aspek
Skor $(\%)$ 


\begin{tabular}{ll}
\hline Penyampaian Materi & 85,4 \\
\hline Kemampuan Pemecahan Masalah & 88,3 \\
\hline Kebermanfaatan & 83,8 \\
\hline Ketertarikan Media & 77,9 \\
\hline
\end{tabular}

Berdasarkan tabel 4 di atas diperoleh hasil respon mahasissa terhadap penggunaan media pembelajaran berbasis edmodo. Aspek pertama ialah penyampaian materi dengan skor $85,4 \%$ yang berisi pengenalan awal pembelajaran dengan moodledan nantinya akan membantu mahasiswa dalam mempelajari kalkulus walaupun tidak tatap muka secara langsung. Aspek kedua ialah kemampuan pemecahan dimana media pembelajaran berbasis moodle dapat mengembangkan kemampuannya secara mandiri serta berdiskusi dengan temannya melalui moodle. Proses pembelajaran dilakukan dengan tahapan yang dasar sampai pada yang sulit.

Walaupun pembelajaran dilakukan dengan tatap muka secara daring diharapkan dapat meningkatkan kemampuan pemecahan masalah mahasiswa. Tahap selanjutnya ialah ketertarikan terhadap media. Media pembelajaran berbasis moodle dapat menarik perhatian mahasiswa dengan pemberian materi secara langsung serta video pembelajaran yang telah disediakan sebelumnya.

\section{Kemampuan Pemecahan Masalah Mahasiswa}

Pada tahapan ini akan dilihat keefektifan media pembelajaran berbasis moodle yang dapat dilihat dari beberapa faktor diantaranya hasil uji kemampuan pemecahan masalah. Langkah pertama dilakukan dengan uji deskriptif kuantitatif. Pada uji ini menggunakan data tes awal mahasisa dan tes akhir menggunaan medoa pembelajaran berbasis edmodo. Haisl uji tersebut dapat dilihat dalam Tabel 5 di bawah ini

Tabel 5. Hasil uji deskriptif pre-test dan post-test

\begin{tabular}{lccc}
\hline Jenis Data & Min & Max & Rata-rata \\
\hline Pretest & 11 & 22 & 16,5 \\
\hline Posttest & 15 & 26 & 20,5 \\
\hline
\end{tabular}

Berdasarkan Tabel 5 hasil uji deskriptif pre-test dan post-test mengalami peningkatan. Dengan demilikan terjadi peningkatan nilai rata-rata yang signifikan. Langkah selanjutnya ialah dengan menghitung $\mathrm{N}$-gain dari nilai pretest dan posttes setiap mahasiswa dan diperoleh hasil dengan beberapa kriteria renda, sedang dan tinggi yang dapat terlihat pada tabel 6

Tabel 6. Kriteria N-gain nilai pre-test dan post-test

\section{Data Rata-rata Kategori}

\begin{tabular}{lll}
\hline Pretest dan posttest & 0,43 & Sedang \\
\hline
\end{tabular}

Tabel 6 menampilkan hasil nilai rata-rata N-gain sebesar 0,42 dengan kategori sedang. Hal ini menyatakan bahwa keefektifan media pembelajaran 
berbais moodle termasuk kategori sedang. Hal ini terlihat jelas bahwa mahasiswa kurang memahami materi yang disampaikan oleh dosen di dalam edmodo. langkah selanjutnya dengan melakukan uji Kolmogorov dan Smirnov. Data yang digunakan untuk uji normalitas Kolmogorov Smirnov ialah nilai rata-rata pretst, posttest dan $\mathrm{N}$-gain. Hasil uji dapat dilihat pada Tabel 7.

Tabel 7. hasil uji Normalitas Kolmogorov Smirnov pretest, posttest dan N-gain

\begin{tabular}{ll} 
Jenis Data & Sig* \\
& \\
\hline Pretest & .975 \\
\hline Posttest & .854 \\
\hline
\end{tabular}

Berdasarkan Tabel 7 di atas terdapat beberapa data pre-test dan post-test berdistribusi normal. Langkah selanjutnya yang dilakkan ialah menggunakan Levene test untuk mengetahui apakah data yang diperoleh homogen atau tidak. Hasil lavene test dapat dilihat pada Tabel 8

Tabel 8. Uji homogenitas pre-test dan post-test

\begin{tabular}{llcl}
\hline Data & Jenis Uji Homogenitas & Sig* & \\
& & & Ket \\
\hline Hasil & Leveme Test & 0.32 & Homogen \\
Pretest & & & \\
dan & & & \\
Posttest & & & \\
\hline
\end{tabular}

Berdasarkan Tabel 8 hasil uji homogenitas dengan Lavene test hasilnya dinyatakan homogen. Langkah selanjutnya ialah dengan melakukan uji Paired Sample T-test. Uji Paired Sample T-Test dilakukan dengan tujuan untuk melihat keefektifan penggunaan media pembelajaran berbasis moodle apakah dapat meningkatkan kemampuan pemecahan masalah mahasiswa, selain itu uji Paired Sample T-Test juga akan menunjukkan perbedaan nyata sebelum dan sesudah menrapkan media pembelajaran berbasis moodle. hasil uji Paired Smaple T-Test dapat dilihat pada Tabel 9.

Tabel 9. Uji Paired sample t-test pre-test dan pos-test

Uraian
Std. Dev


Pembelajaran menggunakan bantuan elektronik mampu memadukan antara perkembangan teknologi dan informasi serta materi pembelajaran (Hatip \& Listiana, 2019; D. Mayasari et al., 2019; Pratama \& Ismiyati, 2019). Pembelajaran dengan menggunakan Moodle juga dapat diterapkan dengan pemberian kuis. Pemberian kuis dengan berbatuan Moodleakan memudahkan pengajar dalam memberikan materi (Dwi Susanti, 2018).

Belajar dengan menggunakan Moodle efektif dalam pembelajaran matematika karena memberikan pengalaman yang baik yaitu memudahkan mahasiswa dalam mengerjakan quiz online yang dapat dilakukan dari mana saja dan kapan saja. Pembelajaran dengan moodle juga dapat menumbuhkan sikap positif karena dapat menumbuhkan semangat dalam belajar dan meningkatkan interaksi antar mahasiswa (Hatip and Listiana, 2019). Oleh karena itu pembelajaran berbasis Moodle efektif digunakan meningkatan kemampuan pemecahan masalah mahasiswa pada mata kuliah Kalkulus 1

\section{SIMPULAN}

Berdasarkan pembahasan hasil penelitian dapat dijawab dari rumusan masalah yang telah dilakukan mengenai efektifitas media pembelajaran berbasis moodle dalam meningkatkan kemampuan pemecahan masalah yang dapat disimpulkan dalam beberapa hal. Pertama, hasil analisis respon siswa dapat diperoleh untuk seluruh pertanyaan mencapai skor rerata 88,85 dengan kategori sangat baik. Mahasiswa memberikan respon positif terhadap pengunaan media pembelajaran berbasis edmodo. Sehingga media pembelajaran berbasis moodlepada mata kuliah kalkulus 1 telah efektif dan dapat digunakan dalam proses pembelajaran. Kedua, hasil antara pretest sebelum menggunakan media pembelajaran berbasis moodle dan post-test setelah menggunakan media pembelajaran berbasis moodle mengalami perbedaan yang signifikan. Meskipun tes kemampuan pemecahan masalah mahasiswa termasuk dalam kategori sedang dalam uji $\mathrm{N}$-gain, media pembelajaran berbasis moodle memiliki kelebihan yaitu mampu meningkatkan kemampuan pemecahan masalah mahasiswa

\section{DAFTAR RUJUKAN}

Chourishi, D. (2015) 'Effective E-Learning through Moodle Moodle for E-learning', INternational Journal of Advance Technology \& Engineering Research (IJATER), 1(August).

Dwi Susanti, R. (2018) 'Penerapan edmodo Pada Pemberian Tes Formatif mahasiswa Pendidikan Profesi Guru Matematika', Jurnal Aksioma, 2(2), pp. 6-11.

Hatip, A. and Listiana, Y. (2019) 'Minat, kemandirian dan Hasil Belajar Mahasiswa Pendidikan Matematika Dalam E-Learning Berbasis Edmodo', Jurnal Program Studi Pendidikan Matematika, 8(3), pp. 485-496.

Kartika:hendra (2013) 'Meningkatkan Kemampuan Pemecahan Masalah Matematis Dan SelfConcept Calon Guru Di Kabupaten Karawang Melaluui Pendekatan Open Ended', Jurnal Aksioma, 53(9), pp. 198-204. doi: 10.1017/CBO9781107415324.004.

Mayasari, D. (2019) 'Penggunaan Matematika Realistik Melalui Media Autograph Untuk Meningkatkan Minat dan Pemecahan masalah matematis', Musamus Journal of Mathematics Education, 2(1).

Mayasari, Dian., Natsir, I. and Munfarikhatin, A. (2019) 'Improving capability of student based on green mathematics through nation character education for caring the environment', in IOP Conference Series: Earth and Environmental Science. doi: 10.1088/1755$1315 / 343 / 1 / 012215$. 
Mayasari, D., Natsir, I. and Munfarikhatin, A. (2019) 'Improving capability of student based on green mathematics through nation character education for caring the environment', IOP Conference Series: Earth and Environmental Science, 343(1), pp. 0-6. doi: 10.1088/1755-1315/343/1/012215.

Pratama, R. An. and Ismiyati, N. (2019) 'Pembelajaran matematika Berbasis edmodo Pada Mata Kuliah teori Bilanga', Jurnal Aksioma, 8(2), pp. 298-309.

Rizal, S. and Walidain, B. (2019) 'Pembuatan Media Pembelajaran E-Learning Berbasis Moodle Pada Matakuliah Pengantar Aplikasi Komputer Universitas Serambi Mekkah', JURNAL ILMIAH DIDAKTIKA: Media Ilmiah Pendidikan dan Pengajaran, 19(2), p. 178. doi: 10.22373/jid.v19i2.5032.

Robson, A. and Polya, G. (1946) How to Solve It, The Mathematical Gazette. doi: $10.2307 / 3609122$.

Sabran and Sabara, E. (2019) 'Keefektifan Google Classroom sebagai media pembelajaran', PROSIDING SEMINAR NASIONAL LEMBAGA PENELITIAN UNIVERSITAS NEGERI Makasar, pp. 122-125

Siswono, E. T. (2018) pembelajaran Matematika Berbasis Pengajuan dan Pemecahan Masalah. 1st edn. Bandung: PT Remaja Rosdakarya.

Smaragdina, A. A. et al. (2020) 'Pelatihan Pemanfaatan dan Pengembangan Bahan Ajar Digital Berbasis Multimedia Interaktif untuk Menghadapi Era Revolusi Industri 4.0', Jurnal KARINOV, 3(1), p. 53. doi: 10.17977/um045v3i1p53-57.

Soni et al. (2018) 'Optimalisasi Pemanfaatan Google Classroom Sebagai Media Pembelajaran Di SMK Negeri 1 Bangkinang', Jurnal Pengabdian Untuk Mu NegeRI, 2(1), pp. 17-20. Available at: https://www.researchgate.net/publication/331703602\%0AOPTIMALISASI.

Sudianto, S., Dwijanto, D. and Dewi, N. R. (2019) 'Students' Creative Thinking Abilities and Self Regulated Learning on Project-Based Learning with LMS Moodle', Unnes Journal of Mathematics Education Research, 8(1), pp. 10-17. Available at: https://journal.unnes.ac.id/sju/index.php/ujmer/article/view/27183.

Syaiful et al. (2017) 'Peningkatan Kemampuan Pemecahan Masalah Matematis Siswa Melalui Pendekatan Pendidikan Matematika Realistik', Logaritma: Jurnal Ilmu-ilmu Pendidikan dan Sains, p. 24. doi: 10.24952/logaritma.v5i01.1258.

Winardi (2015) 'Meningkatkan Kemampuan Pemecahan Masalah dengan Metode MMP dan Pendekatan Open-Ended', Seminar Nasional Matematika dan Pendidikan Matematika, pp. $420-431$. 